NBER WORKING PAPER SERIES

THE IMPACT OF TEACHER-STUDENT GENDER MATCHES: RANDOM ASSIGNMENT EVIDENCE FROM SOUTH KOREA

\author{
Jaegeum Lim \\ Jonathan Meer \\ Working Paper 21407 \\ http://www.nber.org/papers/w21407 \\ NATIONAL BUREAU OF ECONOMIC RESEARCH \\ 1050 Massachusetts Avenue \\ Cambridge, MA 02138 \\ July 2015
}

We are grateful for valuable comments from David Figlio, Mark Hoekstra, Jason Lindo, and James West. The views expressed herein are those of the authors and do not necessarily reflect the views of the National Bureau of Economic Research.

NBER working papers are circulated for discussion and comment purposes. They have not been peerreviewed or been subject to the review by the NBER Board of Directors that accompanies official NBER publications.

(C) 2015 by Jaegeum Lim and Jonathan Meer. All rights reserved. Short sections of text, not to exceed two paragraphs, may be quoted without explicit permission provided that full credit, including $\odot$ notice, is given to the source. 
The Impact of Teacher-Student Gender Matches: Random Assignment Evidence from South Korea Jaegeum Lim and Jonathan Meer NBER Working Paper No. 21407

July 2015

JEL No. I21,I24,J16

\section{$\underline{\text { ABSTRACT }}$}

Gender disparities in academic performance may be driven in part by the interaction of teacher and student gender, but systematic sorting of students into classrooms makes it difficult to identify causal effects. We use the random assignment of students to Korean middle school classrooms and show that the female students perform substantially better on standardized tests when assigned to female teachers; there is little effect on male students.

Jaegeum Lim

Department of Economics

TAMU 4228

College Station, TX 77843

jlim@tamu.edu

Jonathan Meer

Department of Economics

TAMU 4228

College Station, TX 77843

and NBER

jmeer@econmail.tamu.edu 


\title{
The Impact of Teacher-Student Gender Matches: Random Assignment Evidence from South Korea
}

\author{
Jaegeum Lim* \\ Texas A\&M University
}

\author{
Jonathan Meer \\ Texas A\&M University \\ and NBER
}

July 23, 2015

\begin{abstract}
Gender disparities in academic performance may be driven in part by the interaction of teacher and student gender, but systematic sorting of students into classrooms makes it difficult to identify causal effects. We use the random assignment of students to Korean middle school classrooms and show that the female students perform substantially better on standardized tests when assigned to female teachers; there is little effect on male students.
\end{abstract}

\section{Introduction}

Gender gaps in academic performance, with girls generally outperforming boys in language arts and boys generally outperforming girls in math, have persisted despite decades of effort to close them. Understanding the causes of these gaps is crucial, especially at younger ages, as they may lead to gender differences in later course-taking, occupational choices, and labor market outcomes (Lavy and Sand, 2015).

One possible source of gender-based disparities is whether a student and a teacher share the same gender. These gender interactions may affect academic performance through changes in the behavior of both parties. For example, rolemodel effects predict that students will be more engaged in study when they are taught by the same-gender teacher (Dee, 2007). A teacher might behave differently when instructing students of different genders as well, for example, assigning less difficult homework questions to girls if he or she believes that girls are less capable in math than boys (Jones and Dindia, 2004).

The primary threat to identifying the causal effect of teacher-student gender matches is the nonrandom sorting of students that typifies classroom assignment

*Author emails are jlim@.tamu.edu and jmeer@tamu.edu. We are grateful for valuable comments from David Figlio, Mark Hoekstra, Jason Lindo, and James West. 
in most contexts. For instance, students with a lower propensity to achieve academically may be more likely to be assigned to a female teacher. Beginning with Dee (2007), the standard approach in this literature, at least at the primary and secondary school level, has been to use student interactions with multiple teachers, generally across different subjects. By using estimates including student fixed effects, unobserved student characteristics that are correlated with student quality and teacher gender will not bias estimation. Dee uses the fact that the National Education Longitudinal Survey of 1988 surveys two teachers for every student to estimate within-student teacher-gender effects; he finds evidence of substantial positive impacts on academic achievement of being assigned to a teacher of the same gender. Moreover, he uses subjective evaluations of both teacher and student perceptions to show that students are less likely to be seen as disruptive when evaluated by a teacher of the same gender, and more likely to report interest in that academic subject.

On the other hand, Holmlund and Sund (2008) use Swedish secondaryschool panel data and identify the impact of same-gender teachers using teacher turnover; once they control for subject-specific gender effects, they find no impact of gender matching on student performance. Cho (2012) uses math and science test score data from 15 OECD countries and, following Dee (2007)'s identification strategy, shows that there is no significant effect of teacher-student gender matching in eight of these countries, including the United States. Most recently, Paredes (2014) examines role model and teacher bias effects with data from Chile in which students took multiple exams. She finds small but statistically significant gender-matching effects for girls and no effects for boys, as well as suggestive evidence that role model effects drive the result.

However, this within-student estimation approach - even when including teacher fixed effects - is insufficient if students and teachers are systematically matched on characteristics correlated with gender. For instance, suppose female students who would benefit relatively more from having a female teacher are more likely to be assigned to female teachers who, themselves, are better role models for female students. In this case, a positive student-teacher gender interaction effect reflects sorting. As Dee notes, "the internal validity of such within-student comparisons could still be compromised by the nonrandom sorting by students with subject-specific propensities for achievement and by unobserved teacher and classroom traits correlated with gender." With a number of indirect tests, like examining spillovers from having a female math teacher onto science test scores, he finds some such evidence in the NELS:88, particularly in the assignment of female math teachers. Other studies lacking random assignment must also indirectly show that the identification strategy holds; for instance, Paredes (2014) uses previous-year's test scores to control for achievement propensity.

To address this issue, we exploit a unique feature of secondary education in South Korea: the random assignment of students into a classroom, where students remain throughout the school day. We provide evidence for our identifying assumption in a number of ways: first, as-good-as-random assignment of students to classrooms is a strict policy in South Korea. We confirm that 
schools follow this policy by surveying a large number of them on the topic. We also show that assignment to classrooms within a school is uncorrelated with observable characteristics; that students assigned to same- and opposite-gender teachers look similar in their observable characteristics; and that our results do not differ when additional controls, student fixed effects, or teacher fixed effects are included, as one would expect if assignment is truly random.

Our reliance on random assignment obviates potential sorting issues that have been a major concern in previous work. ${ }^{1}$ We also provide more recent evidence from an age group similar to that studied in Dee (2007) and, importantly, our empirical setting is a culture with somewhat different gender norms than those previously studied. South Korea is ranked $39^{t h}$ of 57 countries in its residents' attitudes towards gender equality, much lower than the countries studied in the analyses above: $29^{\text {th }}$ for Chile, $18^{\text {th }}$ for the United States, and $2^{\text {nd }}$ for Sweden (Brandt, 2011). ${ }^{2}$

Our results show that female students' performance is positively influenced by having a female teacher, but that there is little same-gender teacher effect for males. These effects are primarily concentrated in mathematics and English language scores, as compared to Korean language scores. We also provide some suggestive evidence on the mechanisms behind these impacts, with female students reporting that their female teachers are more likely to encourage them and to give them an equal opportunity to express themselves.

\section{Data}

We use cross-sectional data collected by the Korean Educational Development Institute (KEDI) in July of 2004, at the end of the first semester of middle school in South Korea. The target schools, covering $6.8 \%$ of the relevant population in South Korea in 2004, were selected by proportionate stratified random sampling. KEDI surveyed all teachers at the sample schools and all ninth grade students from two classrooms that were randomly chosen from the sample schools. Our initial sample consists of 197 schools, 777 Korean, English, and mathematics teachers linked to surveyed classrooms, 14,372 students, and 11,944 parents. 35 of the schools had all-female students and 34 were all-male.

In addition to an extensive set of questions, students' responses were linked to their scores on the Student Achievement Test, administered by the Seoul Metropolitan Office of Education (SMOE). Students in the sample were tested

\footnotetext{
${ }^{1}$ In this way, our approach is most similar to that of Carrell, Page and West (2010), at the higher education level. They use random assignment of cadets at the United States Air Force Academy to compulsory math and science courses and show that female professors significantly reduce the gender gap in performance for female students. Other evidence on gender-matching effects on student grades, course-taking, and persistence in colleges is mixed; see, for example, Canes and Rosen (1995), Bettinger and Long (2005), and Hoffmann and Oreopoulos (2009).

${ }^{2}$ Our work is also related to the literature on the impact of single-sex schools. Park et al. (2013) find significant positive impacts of single-sex schooling using random assignment in South Korea, while Jackson (2012) exploits the nature of rules-based school assignment in Trinidad and Tobago and finds little effect for most students.
} 
at the beginning of the second semester of ninth grade in three courses: Korean language, English language, and mathematics; 12,363 students' test results were collected. ${ }^{3}$

The teacher questionnaire includes information on teachers' classroom assignments, which we use to link students with their subject teachers. Beginning with 37,034 student-subject combinations with test score information, we first drop 6,033 observations without classroom or teacher information. Of these, 42 observations from 14 students have missing classroom information and 5,991 observations from 224 classrooms do not have teacher information due to nonresponse by teachers; this reduces the number of teachers in the sample to 777 and the number of students to $12,305 .^{4}$ For our primary sample, we also drop 6,442 observations for students with multiple subject teachers, for which we could not make a student-teacher match representing just one student and one teacher; we also show results including these observations, which are unchanged from those excluding them. This results in 24,489 student-teacher pairings representing 11,659 students and 502 teachers. Among them, $33 \%$ of observations correspond to a female student with a female teacher; $16 \%$ are a female student with a male teacher; $32 \%$ are a male student with a female teacher; and the remaining $19 \%$ are male students with male teachers.

\subsection{Classroom assignment in South Korea}

Elementary school graduates in South Korea are randomly assigned to middle schools within their district, though since 1996, students in districts whose superintendents allow it are permitted to list several preferred schools; they are entered into a lottery for each school on their preferred list (Korea Legislation Research Institute, 2011). At the beginning of each academic year (March ${ }^{\text {st }}$ ), middle school students in South Korea are assigned a classroom where they remain throughout a school day, and where each subject teacher visits to present a lesson. Classroom assignment in South Korea is done through some form of randomization; a typical approach is to order students by their academic performance in the previous year and then place them across classrooms. As an example, the top ranked student would be assigned to the first classroom, the second-ranked student assigned to the second classroom, and so on. ${ }^{5}$ Be it pri-

\footnotetext{
${ }^{3}$ This exam is administered to $9^{\text {th }}$ graders in Seoul every September; these students would have taken the test regardless. Students living outside of Seoul but in the KEDI sample took the same exam on the same day.

${ }^{4} \mathrm{~A}$ concern is that teacher non-response could somehow be correlated with their impact on students of different genders. While we cannot completely exclude this possibility, students dropped from the sample due to teacher non-response have similar test scores $(p=0.77)$ as those remaining in the sample. There were also no statistically significant differences in the other student characteristics we examined.

${ }^{5}$ Kang (2007) uses this same random assignment feature and a different data set on the performance of Korean students to examine peer effects. As mentioned above, Park et al. (2013) examine the effect of single-sex education on college-going behavior using data from Seoul, in which students are not allowed to list preferred schools. Lee et al. (2014) examine schools in the Seoul metropolitan area to study the effects of single-sex versus co-educational schooling on academic performance.
} 
vate or public, schools in South Korea use some form of random assignment to classrooms due to strong social norms (Kang, 2007). ${ }^{6}$ In Section 3.1, we further examine whether random assignment holds in our data based on students' observable characteristics.

\section{Methodology}

\subsection{Tests of Random Assignment}

\subsubsection{Pearson's $\chi^{2}$ Tests}

While the institutional setting we study is clear that students are randomized across classrooms without respect to teacher gender, we also provide empirical evidence to support our identification strategy. We begin by testing whether students are randomly assigned to classrooms with respect to their observable characteristics, conducting a series of Pearson's $\chi^{2}$ tests for independence of a variety of characteristics and the classroom to which they are assigned. Tested characteristics include student's gender, parents' marital status, parents' education, as well as whether parents own their own home and whether student's home has access to the Internet, as proxies for family resources. Parents' education has seven categories and the other variables are indicator variables.

We perform 2,082 Pearson's $\chi^{2}$ tests across six characteristics and 453 schoolsubject combinations. ${ }^{7} 115$ of these p-values are lower than or equal to five percent, rejecting the null hypothesis of independence for $5.2 \%$ of the tests. Therefore, there is little evidence of nonrandom assignment of students into classroom with respect to student's observable characteristics.

To check whether the rejections are concentrated in particular schools, we examine distributions of the number of rejections by school. Figure 1 shows the distributions for all subjects and each subject. Two schools have a total of six rejections in all subjects combined and one school has five rejections. Only one school has as many as three rejections in one subject, suggesting that no schools that are failing to comply with the random assignment of students to classrooms. Further, omitting the three schools with five or six total rejections from our estimates does not affect the results.

\subsubsection{Difference in Mean Characteristics}

Another approach is to compare the groups of students taught by same- and opposite-gender teachers. If the students are randomly assigned to the teachers of the same and opposite gender, then the two groups should look similar in terms of observable characteristics.

\footnotetext{
${ }^{6}$ To confirm this point, we surveyed local Offices of Education on schools' rules for classroom assignment for the 197 schools in our sample. Every one of the 181 schools which responded reported that they used some form of random assignment, excepting one school which only had one classroom for each grade.

${ }^{7}$ Some combinations cannot be tested due to missing variables, only a single classroom from the school remaining in the sample, or the school itself being single-sex.
} 


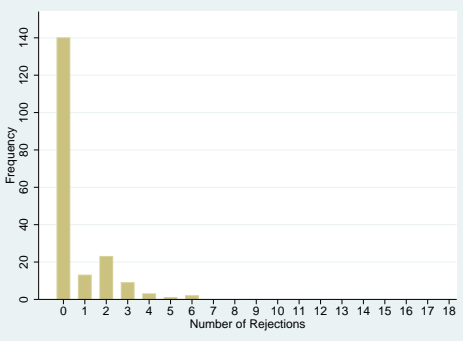

(a) All Subjects

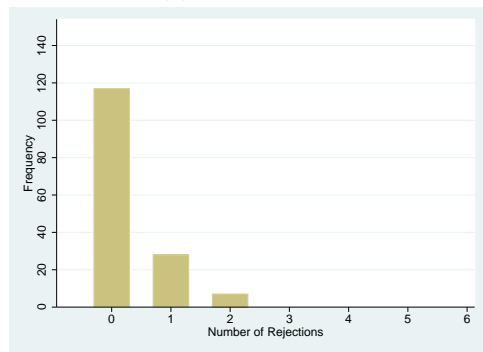

(c) English Language

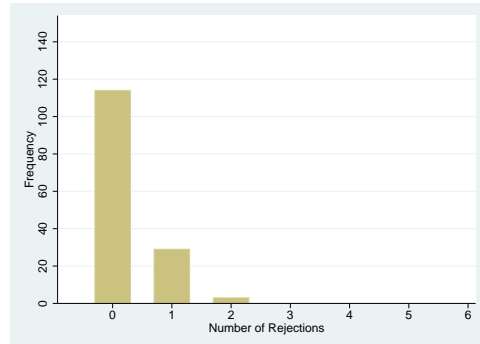

(b) Korean Language

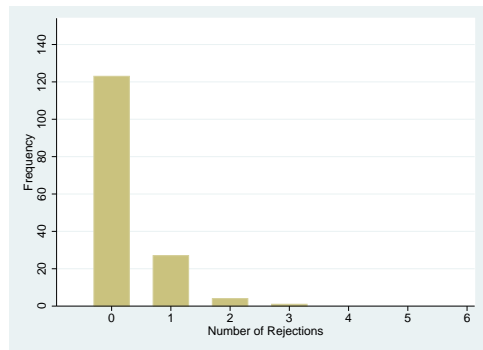

(d) Mathematics

Figure 1: Rejections of Classroom-Characteristic Independence by School

Table 1 presents sample means from our data, with each observation as a student-teacher pair. Recall that the randomization in our sample is within schools, though even when looking across schools, the results are fairly wellbalanced. In Panel A, the characteristics for female and male students are presented separately by teacher gender, demonstrating that students are not more likely to be assigned to a teacher of the same gender based on observable characteristics. For male students, there is a statistically significant difference for home ownership, but it is economically small; moreover, since random assignment was done within schools, adjusting for school fixed effects eliminates the significance of this difference. We also show the mean standardized test scores by group as a preview of our results. Female students perform substantially better than male students overall, but particularly when they have female teachers; meanwhile, male students are not greatly affected by the gender of their teacher. In Panel B, we compare teachers' characteristics when assigned female and male students. As in most schools around the world, female teachers are much more prevalent in our sample, but there are no significant differences in the types of teachers assigned to students of different gender. These results further show that students and teachers are randomly assigned to classrooms irrespective of gender matches. 
Table 1: Comparison of Mean Characteristics

\begin{tabular}{|c|c|c|c|c|c|c|c|c|}
\hline \multirow[t]{2}{*}{ A. Student Characteristics } & \multicolumn{4}{|c|}{ Female Students } & \multicolumn{4}{|c|}{ Male Students } \\
\hline & $\begin{array}{l}\text { Female } \\
\text { Teachers }\end{array}$ & $\begin{array}{c}\text { Male } \\
\text { Teachers }\end{array}$ & $\mathrm{P}$-value & Observations & $\begin{array}{l}\text { Female } \\
\text { Teachers }\end{array}$ & $\begin{array}{c}\text { Male } \\
\text { Teachers }\end{array}$ & P-value & Observations \\
\hline Married Parent & $\begin{array}{c}0.903 \\
(0.007)\end{array}$ & $\begin{array}{c}0.899 \\
(0.006)\end{array}$ & 0.673 & 10,326 & $\begin{array}{c}0.901 \\
(0.006)\end{array}$ & $\begin{array}{c}0.893 \\
(0.007)\end{array}$ & 0.315 & 10,059 \\
\hline Dad w/ College or More & $\begin{array}{c}0.263 \\
(0.022)\end{array}$ & $\begin{array}{c}0.223 \\
(0.023)\end{array}$ & 0.086 & 10,073 & $\begin{array}{c}0.269 \\
(0.021)\end{array}$ & $\begin{array}{c}0.223 \\
(0.025)\end{array}$ & 0.115 & 9,751 \\
\hline Mom w/ College or More & $\begin{array}{c}0.143 \\
(0.017)\end{array}$ & $\begin{array}{c}0.126 \\
(0.018)\end{array}$ & 0.338 & 10,135 & $\begin{array}{c}0.145 \\
(0.016)\end{array}$ & $\begin{array}{c}0.119 \\
(0.020)\end{array}$ & 0.270 & 9,688 \\
\hline Parents Own Home & $\begin{array}{c}0.711 \\
(0.015)\end{array}$ & $\begin{array}{c}0.732 \\
(0.016)\end{array}$ & 0.264 & 10,476 & $\begin{array}{c}0.716 \\
(0.013)\end{array}$ & $\begin{array}{c}0.748 \\
(0.013)\end{array}$ & 0.033 & 10,202 \\
\hline Internet Access at Home & $\begin{array}{c}0.916 \\
(0.006)\end{array}$ & $\begin{array}{c}0.912 \\
(0.007)\end{array}$ & 0.616 & 10,272 & $\begin{array}{c}0.907 \\
(0.006)\end{array}$ & $\begin{array}{c}0.903 \\
(0.007)\end{array}$ & 0.580 & 9,939 \\
\hline Standardized Test Score & $\begin{array}{c}0.114 \\
(0.030)\end{array}$ & $\begin{array}{c}0.057 \\
(0.044)\end{array}$ & 0.181 & 11,925 & $\begin{array}{l}-0.100 \\
(0.037)\end{array}$ & $\begin{array}{l}-0.089 \\
(0.042)\end{array}$ & 0.827 & 12,306 \\
\hline \multicolumn{9}{|l|}{ B. Teacher Characteristics } \\
\hline & \multicolumn{4}{|c|}{ Female Teachers } & \multicolumn{4}{|c|}{ Male Teachers } \\
\hline & $\begin{array}{c}\text { Female } \\
\text { Students }\end{array}$ & $\begin{array}{c}\text { Male } \\
\text { Students }\end{array}$ & $\mathrm{P}$-value & Observations & $\begin{array}{l}\text { Female } \\
\text { Students }\end{array}$ & $\begin{array}{c}\text { Male } \\
\text { Students }\end{array}$ & P-value & Observations \\
\hline Teacher Age & $\begin{array}{c}36.2 \\
(0.575)\end{array}$ & $\begin{array}{c}35.8 \\
(0.567)\end{array}$ & 0.515 & 15,719 & $\begin{array}{c}43.0 \\
(0.963)\end{array}$ & $\begin{array}{c}43.6 \\
(0.811)\end{array}$ & 0.569 & 8,406 \\
\hline Teacher Experience (year) & $\begin{array}{c}11.8 \\
(0.605)\end{array}$ & $\begin{array}{c}11.4 \\
(0.614)\end{array}$ & 0.524 & 15,265 & $\begin{array}{c}17.0 \\
(0.975)\end{array}$ & $\begin{array}{c}18.0 \\
(0.952)\end{array}$ & 0.414 & 8,315 \\
\hline Teachers College Graduate & $\begin{array}{c}0.759 \\
(0.030)\end{array}$ & $\begin{array}{c}0.736 \\
(0.030)\end{array}$ & 0.467 & 15,794 & $\begin{array}{c}0.633 \\
(0.063)\end{array}$ & $\begin{array}{c}0.614 \\
(0.048)\end{array}$ & 0.777 & 8,406 \\
\hline Graduate Degree Teacher & $\begin{array}{c}0.207 \\
(0.029)\end{array}$ & $\begin{array}{c}0.204 \\
(0.032)\end{array}$ & 0.923 & 15,794 & $\begin{array}{c}0.454 \\
(0.052)\end{array}$ & $\begin{array}{c}0.401 \\
(0.057)\end{array}$ & 0.382 & 8,406 \\
\hline Homeroom Teacher & $\begin{array}{c}0.787 \\
(0.030)\end{array}$ & $\begin{array}{c}0.824 \\
(0.024)\end{array}$ & 0.216 & 15,672 & $\begin{array}{c}0.601 \\
(0.049)\end{array}$ & $\begin{array}{c}0.660 \\
(0.048)\end{array}$ & 0.318 & 8,319 \\
\hline Regular Full Time Teacher & $\begin{array}{c}0.956 \\
(0.013)\end{array}$ & $\begin{array}{c}0.962 \\
(0.011)\end{array}$ & 0.518 & 15,647 & $\begin{array}{c}0.967 \\
(0.022)\end{array}$ & $\begin{array}{c}0.980 \\
(0.015)\end{array}$ & 0.633 & 8,360 \\
\hline
\end{tabular}




\subsection{Specifications}

To analyze the effect of teacher-student gender interaction, we estimate the following linear regression equation:

$$
y_{i j s b}=\beta_{0}+\beta_{1} f s_{i}+\beta_{2} f t_{j}+\beta_{3} f s_{i} f t_{j}+X_{i j} \gamma^{\prime}+\alpha_{s}+\alpha_{b}+\varepsilon_{i j s b},
$$

where $y_{i j s b}$ is the test score of student $i$ who was taught by teacher $j$ in school $s$ for subject $b$. The test scores are normalized in each subject to have mean zero and variance of one. Because the scores in Korean language, English language and math are pooled together, we also include subject fixed effects $\alpha_{b} . f s_{i}$ and $f t_{j}$ are indicator variables having value of one when student $i$ and teacher $j$, respectively, are female. $X_{i j}$ is a vector of student and teacher characteristics including indicators for married parents and parental education; teacher characteristics include indicators for graduate degree and graduation from a teachers college, and indicators for teacher experience of two years or below, two to three years, three to four years, four to five years, and five years or more. $\alpha_{s}$ are school fixed effects, included since random assignment of students is done within schools.

We estimate the equations by ordinary least squares (OLS), which produces unbiased estimates given the random assignment of students and teachers to classrooms. Standard errors are clustered at the school level to accommodate correlations among students within the same schools; we obtain similar standard errors clustering at the classroom level or with two-way clustering at the student and teacher level.

$\beta_{1}$ is the average difference in academic achievement for female compared to male students with male teachers, while $\beta_{2}$ indicates the impact of a female versus male teacher on performance for male students. The total effect of having a female teacher for female students can be obtained by adding $\beta_{2}$ to $\beta_{3}$, with $\beta_{3}$ as the differential effect on female students, as compared to male students, of having a female teacher. This last coefficient is the change in the gender gap between female and male students when switching from a male teacher to a female teacher.

\section{Results}

\subsection{Main Effects}

Table 2 presents the coefficients from estimating variations of Equation (1). All columns include school fixed effects because random assignment is done within a school, as well as subject fixed effects. In Columns 3 and 4, student fixed effects subsume the school fixed effects; in Column 4, teacher fixed effects subsume the subject effects.

In Column 1, the coefficient on the female student variable indicates that female students perform better than male student by about 0.15 of a standard

deviation on average across Korean language, English language, and math when 
paired with a male teacher. The change in the performance gender gap between females and males when switching from a male teacher to a female teacher, as indicated by the interaction effect between female student and female teacher, is 0.097 standard deviations. This total effect is comprised of a small and statistically insignificant decrease in male performance of 0.021 standard deviations and an increase in female performance of 0.076 . This widening of the gender gap is substantial, representing more than a third of a year of schooling based on the general rule of thumb that $1 \%$ of a standard deviation of performance is roughly equivalent to 10 days of schooling (Carlsson et al., 2012).

Table 2: Main Results

\begin{tabular}{|c|c|c|c|c|c|}
\hline & \multicolumn{4}{|c|}{ Single Teacher Only } & \multirow{2}{*}{$\begin{array}{c}\text { Single and } \\
\text { Multiple Teachers } \\
(5)\end{array}$} \\
\hline & (1) & $(2)$ & $(3)$ & (4) & \\
\hline Female Student & $\begin{array}{l}0.1469^{* * *} \\
(0.0303)\end{array}$ & $\begin{array}{l}0.1444^{* * *} \\
(0.0305)\end{array}$ & & & $\begin{array}{l}0.1484^{* * *} \\
(0.0289)\end{array}$ \\
\hline Female Teacher & $\begin{array}{r}-0.0214 \\
(0.0288)\end{array}$ & $\begin{array}{c}-0.0219 \\
(0.0287)\end{array}$ & $\begin{array}{r}-0.0100 \\
(0.0452)\end{array}$ & & $\begin{array}{r}-0.0280 \\
(0.0245)\end{array}$ \\
\hline $\begin{array}{l}\text { Female Student } \times \\
\text { Female Teacher }\end{array}$ & $\begin{array}{l}0.0976^{* * *} \\
(0.0317)\end{array}$ & $\begin{array}{l}0.1053^{* * *} \\
(0.0322)\end{array}$ & $\begin{array}{l}0.1025^{* *} \\
(0.0511)\end{array}$ & $\begin{array}{r}0.0939^{*} \\
(0.0488)\end{array}$ & $\begin{array}{l}0.1030^{* * *} \\
(0.0299)\end{array}$ \\
\hline Constant & $\begin{array}{l}-0.0928^{* * *} \\
(0.0211)\end{array}$ & $\begin{array}{l}-0.1099^{* * *} \\
(0.0399)\end{array}$ & $\begin{array}{r}-0.0295 \\
(0.0194)\end{array}$ & $\begin{array}{c}-0.0332^{* *} \\
(0.0163)\end{array}$ & $\begin{array}{c}-0.0869^{* * *} \\
(0.0186)\end{array}$ \\
\hline Observations & 24,231 & 23,580 & 24,231 & 24,231 & 30,673 \\
\hline$R^{2}$ & 0.1100 & 0.1121 & 0.8492 & 0.8595 & 0.1061 \\
\hline School FE & Yes & Yes & No & No & Yes \\
\hline Student FE & No & No & Yes & Yes & No \\
\hline Teacher Controls & No & Yes & No & No & No \\
\hline Teacher FE & No & No & No & Yes & No \\
\hline Subject FE & Yes & Yes & Yes & No & Yes \\
\hline
\end{tabular}

Including teacher background controls in Column 2 does not change the coefficients of our interest much. ${ }^{8}$ We include student fixed effects in Column 3 to test for the presence of unobserved student characteristics correlated with the variables of interest. They do not change the gender gap appreciably. Finally, in Column 4, we add teacher fixed effects to specification in Column 3 to test whether unobserved teacher characteristics are driving our results, despite random assignment. The teacher-student gender interaction coefficient remains the same size and is statistically significant at $p=0.056$. Taken together with the evidence in Section 3.1, the stability of this coefficient strongly suggests that the random assignment to classrooms in South Korea is, indeed, in place. As such, the interpretation of our results is free of the potential problems caused by sorting on unobservable characteristics.

To show that our results are not affected by the 6,442 observations that were

\footnotetext{
${ }^{8}$ Results are similar when including a variety of student background characteristics, but nonresponses in the data reduce the sample substantially.
} 
dropped due to students having multiple subject teachers, we include them in Column 5. This specification corresponds to that in Column 1, but the female teacher variable represents the fraction of the student's subject teachers who are female. About $90 \%$ of these additional observations are groups of two teachers; nearly all of the remaining ones have three teachers. The results are essentially unchanged, with the gender gap increasing by 0.10 standard deviations when all of a female student's teachers are female themselves.

\subsection{Effects by Subject}

The gender gap differs substantially by subject, with female students generally performing substantially better than males in language arts but about even or slightly worse in science and mathematics (OECD, 2015). Teachers' impacts may be greater in mathematics, given negative stereotypes about female mathematical ability; for example, Spencer, Steele and Quinn (1999)'s experimental study shows that negative stereotypes regarding the mathematical ability of female students negatively affects their test scores.

To test whether our results vary by subject, we fully interact the specification in Column 1 of Table 2 with indicators for English and mathematics. The coefficients, in Panel A of Table 3, show the full set of interactions. We note that female students perform far better than male students in Korean (0.34 standard deviations) and English (0.20 standard deviations), and about evenly in math (-0.04 standard deviations), with the last of these differences being statistically insignificant. In Panel B, we combine the relevant coefficients to calculate the change in the gender gap between female and male performance when switching from a male to female teacher. For Korean language courses, the gender gap between girls and boys does not widen significantly, though it does for English and math; however, there are no statistically significant differences between these effects.

\subsection{Evidence on Mechanisms}

To investigate the mechanisms underlying the positive impact of female teachers on female students, we examine a series of student responses about classroom interactions, as well as questions about private tutoring asked of parents. There are numerous such questions in the KEDI data, but we chose to focus primarily on those relating to the student's behavior in class and perceptions of the teacher. Columns 1 to 5 correspond to the specification in Column 1 of Table 2, in which the dependent variable is an indicator for whether the student agrees or agrees strongly with the following sentiments: I feel comfortable asking the teacher a question; the teacher provides students with equal opportunity to participate in class; the teacher encourages students to express themselves; this is my favorite subject; and I ask many questions in this class. In Column 6 , the dependent variable is a continuous measure of hours of study in that subject (excluding hours spent at tutoring). Column 7, asked of parents, reports the likelihood of receiving tutoring in the subject; note that over $60 \%$ of students 
Table 3: Results by Subject

\begin{tabular}{|c|c|}
\hline \multicolumn{2}{|l|}{ A. Main $\mathcal{G}$ Interaction Effects } \\
\hline Female Student & $\begin{array}{c}0.3357^{* * *} \\
(0.0398)\end{array}$ \\
\hline Female Teacher & $\begin{array}{c}-0.0351 \\
(0.0391)\end{array}$ \\
\hline Female Student $\times$ Female Teacher & $\begin{array}{c}0.0423 \\
(0.0473)\end{array}$ \\
\hline English $\times$ Female Student & $\begin{array}{c}-0.1347^{* * *} \\
(0.0485)\end{array}$ \\
\hline Math $\times$ Female Student & $\begin{array}{c}-0.3803^{* * *} \\
(0.0462)\end{array}$ \\
\hline English $\times$ Female Teacher & $\begin{array}{c}0.0487 \\
(0.0520)\end{array}$ \\
\hline Math $\times$ Female Teacher & $\begin{array}{c}0.0209 \\
(0.0481)\end{array}$ \\
\hline English $\times$ Female Student $\times$ Female Teacher & $\begin{array}{c}0.0567 \\
(0.0601)\end{array}$ \\
\hline Math $\times$ Female Student $\times$ Female Teacher & $\begin{array}{c}0.0422 \\
(0.0608)\end{array}$ \\
\hline Constant & $\begin{array}{c}-0.1561^{* * *} \\
(0.0267)\end{array}$ \\
\hline \multicolumn{2}{|l|}{ B. Change in the Performance Gap } \\
\hline Korean Language & $\begin{array}{c}0.0423 \\
(0.0473)\end{array}$ \\
\hline English Language & $\begin{array}{c}0.0989^{* *} \\
(0.0448)\end{array}$ \\
\hline Math & $\begin{array}{l}0.0845^{* *} \\
(0.0409)\end{array}$ \\
\hline $\begin{array}{l}\text { Observations } \\
R^{2}\end{array}$ & $\begin{array}{l}24,231 \\
0.1152\end{array}$ \\
\hline
\end{tabular}


receive tutoring. In Column 8 , we examine the effect on the log of tutoring expenditures, conditional on reporting any. This variable, reported by parents as well, provides an indication of tutoring intensity, both in terms of time and personal attention.

It is interesting to note that all students report greater comfort in asking questions when the teacher is female, but there is no additional effect on female students. Female students are significantly less likely to feel as if they have an equal opportunity to participate or are encouraged with male teachers, but this negative outcome is eliminated when the teacher is female. Female students are also significantly more likely to report that the subject is their favorite when the teacher is female, though interestingly enough, they are less likely to report asking many questions. There is no effect on hours of study, nor on either tutoring outcome variable.

Taken together, these results provide some suggestive evidence that the increase in female student performance with female teachers is driven by teacher rather than student behavior. Female students do not report increased effort as reflected in studying or tutoring, but they do report feeling that female teachers provide a more inclusive learning environment. We are careful not to draw too strong of a conclusion, though. After all, if female students are learning more effectively in classrooms with female teachers due to role model effects, they are less likely to need to put forth additional effort outside of the classroom.

\section{Conclusion}

Understanding the effect of teacher-student gender interactions on student's academic achievement is important not only for evaluating policies to close the gender gap in academic achievement, but also to enhance understanding of the education production function. However, it is difficult to estimate a studentteacher gender match effect free of selection bias because of the nonrandom sorting of students.

In this study, we estimate the impact of teacher-student gender matches on academic achievement using the random assignment of students in South Korea. We find that the performance gender gap between female and male students increases dramatically when switching from male to female teachers. Male students do not appear to benefit from a teacher of the same gender, but female students' performance increases by about $8 \%$ of a standard deviation when they are taught by a female teacher. This effect is large, and driven primarily by performance in English and mathematics courses. We provide suggestive but not conclusive evidence that teacher behavior drives this increase in student achievement. Our findings are consistent with previous results that find that gender interactions matter. Given the random assignment nature of our data, we conclude that these interactions reflect genuine changes in the classroom environment rather than sorting on unobservables. 
Table 4: Effects on Student and Teacher Behavior

\begin{tabular}{|c|c|c|c|c|c|c|c|c|c|}
\hline & & $\begin{array}{l}\text { Comfort Asking } \\
\text { Questions } \\
\text { (1) }\end{array}$ & $\begin{array}{c}\text { Equal Chance } \\
\text { to Participate } \\
(2)\end{array}$ & $\begin{array}{c}\text { Teacher } \\
\text { Encourages } \\
\text { Expression } \\
(3)\end{array}$ & $\begin{array}{c}\text { Favorite } \\
\text { Subject } \\
(4)\end{array}$ & $\begin{array}{c}\text { Asks Many } \\
\text { Questions } \\
(5)\end{array}$ & $\begin{array}{l}\text { Hours of } \\
\text { Study } \\
(6)\end{array}$ & $\begin{array}{c}\text { Receives } \\
\text { Tutoring } \\
(7)\end{array}$ & $\begin{array}{c}\text { Log Tutoring } \\
\text { Expenditures } \\
\text { (8) }\end{array}$ \\
\hline & Female Student & $\begin{array}{c}-0.0285 \\
(0.0192)\end{array}$ & $\begin{array}{c}-0.0504^{* * *} \\
(0.0176)\end{array}$ & $\begin{array}{c}-0.0560^{* * * *} \\
(0.0173)\end{array}$ & $\begin{array}{c}-0.0066 \\
(0.0164)\end{array}$ & $\begin{array}{c}-0.0204^{* *} \\
(0.0089)\end{array}$ & $\begin{array}{c}-0.1369 \\
(0.0941)\end{array}$ & $\begin{array}{c}-0.0788^{* * *} \\
(0.0179)\end{array}$ & $\begin{array}{c}0.0306 \\
(0.0480)\end{array}$ \\
\hline & Female Teacher & $\begin{array}{l}0.0500^{* *} \\
(0.0205)\end{array}$ & $\begin{array}{c}0.0391^{*} \\
(0.0219)\end{array}$ & $\begin{array}{c}0.0122 \\
(0.0209)\end{array}$ & $\begin{array}{c}-0.0049 \\
(0.0155)\end{array}$ & $\begin{array}{l}0.0290^{* * *} \\
(0.0102)\end{array}$ & $\begin{array}{c}-0.0463 \\
(0.0610)\end{array}$ & $\begin{array}{c}-0.0139 \\
(0.0137)\end{array}$ & $\begin{array}{c}-0.0387 \\
(0.0308)\end{array}$ \\
\hline \multirow[t]{5}{*}{$\vec{\omega}$} & $\begin{array}{l}\text { Female Student } \times \\
\text { Female Teacher }\end{array}$ & $\begin{array}{c}0.0084 \\
(0.0227)\end{array}$ & $\begin{array}{l}0.0603^{* * *} \\
(0.0222)\end{array}$ & $\begin{array}{l}0.0630^{* * *} \\
(0.0196)\end{array}$ & $\begin{array}{l}0.0407^{* *} \\
(0.0196)\end{array}$ & $\begin{array}{c}-0.0206^{*} \\
(0.0109)\end{array}$ & $\begin{array}{c}0.0627 \\
(0.0966)\end{array}$ & $\begin{array}{c}0.0165 \\
(0.0181)\end{array}$ & $\begin{array}{c}-0.0796 \\
(0.0487)\end{array}$ \\
\hline & Constant & $\begin{array}{l}0.3145^{* * *} \\
(0.0143)\end{array}$ & $\begin{array}{l}0.3789^{* * *} \\
(0.0154)\end{array}$ & $\begin{array}{l}0.3321^{* * *} \\
(0.0144)\end{array}$ & $\begin{array}{l}0.2859^{* * *} \\
(0.0108)\end{array}$ & $\begin{array}{l}0.0992^{* * *} \\
(0.0068)\end{array}$ & $\begin{array}{l}1.8569^{* * *} \\
(0.0524)\end{array}$ & $\begin{array}{l}0.6228^{* * *} \\
(0.0117)\end{array}$ & $\begin{array}{l}2.2225^{* * *} \\
(0.0267)\end{array}$ \\
\hline & Observations & 23,755 & 23,773 & 23,737 & 23,900 & 24,065 & 24,227 & 17,812 & 6,788 \\
\hline & $R^{2}$ & 0.0361 & 0.0532 & 0.0552 & 0.0282 & 0.0280 & 0.0443 & 0.1203 & 0.1941 \\
\hline & \multicolumn{9}{|c|}{$\begin{array}{l}\text { Notes: Each column represents a separate regression and includes subject and school fixed effects. The response variables for Columns (1) through (5) are indicators taking value of one if a student } \\
\text { agrees or strongly agrees with the statement that (1) I feel comfortable asking the subject teacher a question when the lecture is difficult to understand; }(2) \text { the subject teacher gives all students an } \\
\text { equal opportunity to participate in class; ( }(3) \text { the subject teacher encourages students to be creative and express themselves; }(4) \text { this subject is one of my favorites; }(5) \text { I ask many questions in this } \\
\text { class. The outcome variable in Column } 6 \text { is self-reported study hours per week for the subject, excluding hours spent at tutoring. The outcome in Column } 7 \text { is an indicator for receiving tutoring and } \\
\text { that for Column } 8 \text { is the log of tutoring expenditures. Column } 8 \text { is regressed conditional on positive expenditures. Standard errors in parentheses are clustered at school level. } \\
{ }^{*} p<0.10,{ }^{* *} p<0.05,{ }^{* * *} p<0.01\end{array}$} \\
\hline
\end{tabular}




\section{References}

Bettinger, Eric P. and Bridget Terry Long, "Do faculty serve as role models? The impact of instructor gender on female students," American Economic Review, 2005, pp. 152-157.

Brandt, M. J., "Sexism and gender inequality across 57 societies," Psychological science, 2011, 22 (11), 1413-8.

Canes, Brandice J. and Harvey S. Rosen, "Following in Her Footsteps? Faculty Gender Composition and Women's Choices of College Majors," Industrial and Labor Relations Review, 1995, 48 (3), 486-504.

Carlsson, Magnus, Gordon B. Dahl, Björn Öckert, and Dan-Olof Rooth, "The effect of schooling on cognitive skills," Review of Economics and Statistics, 2012, (0).

Carrell, Scott E., Marianne E. Page, and James E. West, "Sex and Science: How Professor Gender Perpetuates the Gender Gap," Quarterly Journal of Economics, 2010, 125 (3), 1101-1144.

Cho, Insook, "The effect of teacher student gender matching: Evidence from OECD countries," Economics of Education Review, 2012, 31 (3), 54-67.

Dee, Thomas S., "Teachers and the gender gaps in student achievement," Journal of Human Resources, 2007, 42 (3), 528-554.

Hoffmann, Florian and Philip Oreopoulos, "A professor like me: the influence of instructor gender on college achievement," Journal of Human Resources, 2009, 44 (2), 479-494.

Holmlund, Helena and Krister Sund, "Is the gender gap in school performance affected by the sex of the teacher?," Labour Economics, 2008, 15 (1), $37-53$.

Jackson, C Kirabo, "Single-sex schools, student achievement, and course selection: Evidence from rule-based student assignments in Trinidad and Tobago," Journal of Public Economics, 2012, 96 (1), 173-187.

Jones, Susanne M. and Kathryn Dindia, "A meta-analytic perspective on sex equity in the classroom," Review of Educational Research, 2004, 74 (4), $443-471$.

Kang, Changhui, "Classroom peer effects and academic achievement: Quasirandomization evidence from South Korea," Journal of Urban Economics, 2007, 61 (3), 458-495.

Korea Legislation Research Institute, "Enforcement Decree of the Elementary and Secondary Eduation Act, Article 68 (Methods for Entering Middle Schools)," Presidential Decree No.22712, Mar 18, 2011. 
Lavy, Victor and Edith Sand, "On The Origins of Gender Human Capital Gaps: Short and Long Term Consequences of Teachers Stereotypical Biases," NBER Working Paper No. 20909, 2015.

Lee, Soohyung, Lesley J Turner, Seokjin Woo, and Kyunghee Kim, "All or Nothing? The Impact of School and Classroom Gender Composition on Effort and Academic Achievement," NBER Working Paper No. 20722, 2014.

OECD, The ABC of Gender Equality in Education: Aptitude, Behaviour, Confidence, PISA, OECD Publishing, 2015. http://dx.doi.org/10.1787/ 9789264229945-en.

Paredes, Valentina, "A teacher like me or a student like me? Role model versus teacher bias effect," Economics of Education Review, 2014, 39 (2), $38-49$.

Park, Hyunjoon, Jere R Behrman, and Jaesung Choi, "Causal effects of single-sex schools on college entrance exams and college attendance: Random assignment in Seoul high schools," Demography, 2013, 50 (2), 447-469.

Spencer, Steven J., Claude M. Steele, and Diane M. Quinn, "Stereotype threat and women's math performance," Journal of experimental social psychology, 1999, 35 (1), 4-28. 